\title{
O diálogo do RPG digital com a literatura fantástica e o maravilhoso
}

SILVEIRA, Gabriela Rodrigues; Graduanda; UFPel gabisilveira1@hotmail.com

Orientadora: FARIA, Mônica Lima de; Doutora; UFPel

monicalfaria@gmail.com

Palavras-Chave: RPG, fantástico, maravilhoso, literatura, concept art.

Resumo: O presente trabalho é um fragmento de uma pesquisa maior cujo objetivo é estudar a relação entre literatura fantástica, maravilhosa e jogos de RPG a fim de desenvolver concept arts para um mundo de RPG online hipotético. Neste trecho são discutidas as nuances entre os dois gêneros literários - com base na pesquisa de Todorov - e como empregar seus conceitos na narrativa de um jogo de RPG. Por fim foram determinadas algumas estratégias a serem tomadas no desenvolvimento dessas concept arts a fim de conquistar a afeição do público-alvo por meio da identificação.

\section{Introdução}

Em virtude da popularização dos jogos de RPG - role playing games - na contemporaneidade até mesmo $o$ ato de ler toma uma nova configuração - que não exclui seu arranjo original. Levando então em consideração a relação entre o jogo de RPG e a narrativa torna-se coerente um estudo sobre como esse vínculo se apresenta, sendo estre um dos objetivos deste trabalho. Além disso, busca-se ainda explorar a relação do jogo digital com a literatura fantástica e maravilhosa, a fim de se utilizar de seus conceitos para de fazer com que a narrativa do jogo seja concisa e atrativa para o jogador, buscando a identificação com seu público-alvo.

\section{O jogo de RPG como narrativa}

Se por um lado a sociedade contemporânea é guiada pela racionalização, por outro, as pessoas buscam cada vez mais escapar para o mundo da fantasia e da imaginação. $\mathrm{Na}$ atualidade, é comum que livros se expandam para as páginas de quadrinhos, telas de cinema e ainda dos computadores. Isso nada mais é do que uma demonstração de que a literatura se encontra absorta nos meios de comunicação do século atual (CUPERTINO, 2008).

Um dos grandes responsáveis pela popularização desde estilo de jogo foi o Dungeons and Dragons (D\&D), um RPG de mesa, desenvolvido no ano de 1974. A mecânica deste jogo se dá por meio de um mestre, que conduz a narrativa, sendo responsável pela imersão dos jogadores - que atuam como suas personagens (MARTINEZ, MUSTARO E MODESTO, 2014). Ademais, segundo Coutinho (2008), o princípio de se jogar um RPG digital também consiste em elaborar uma personagem que 
irá representar o jogador e a partir disso então percorrer o universo do jogo. Para o autor, a partir do momento que existe uma interação entre a personagem e o mundo já é possível considerar a existência de uma narrativa, afinal a narrativa não precisa obrigatoriamente estar contida em uma organização textual. Aliás, esta pode sim, se manifestar por meio da trama que se passa do jogo, mas também pode se revelar através do diálogo da personagem com o ambiente.

Müeller ainda complementa que as personagens são o principal elemento de grande parte dos jogos digitais atuais, uma vez que sua interação com os demais componentes do jogo é o que faz o enredo se desenrolar, tornando suas ações o cerne da narrativa. (2011). Em outras palavras, com o decorrer da história a trama pode ser revelada e desenvolvida a partir de diversos elementos apresentados no jogo, que não necessariamente o textual, sendo nada mais que uma variação da narrativa tradicional.

\section{A tênue linha entre o Fantástico e o Maravilhoso}

Uma vez que este trabalho visa estudar a relação entre os jogos de RPG e as literaturas fantástica e maravilhosa, faz-se relevante um estudo acerca das nuances entre os dois gêneros. A partir desta perspectiva, é importante ressaltar a atribuição que o design possui frente a criações deste âmbito: "pensando no aspecto criativo na concepção de ambientes, criaturas e situações que não existem no concreto" (LUERSEN, 2010, p.12). O cenário da literatura fantástica se dá por meio de um universo racional como o nosso, num mundo cujas regras e leis se assemelham com as da nossa realidade. Esta sensação cotidiana do ambiente no qual o personagem está inserido é quebrada por algum fenômeno sobrenatural, que faz com que o protagonista (ou o leitor) seja posto em estado de hesitação constante, começando a questionar verdades que antes tomava como incontestáveis (TODOROV, 2010).

Uma vez que é criada a atmosfera de incerteza, existem dois caminhos que podem ser tomados para tentar compreender o que aconteceu: um deles seria optar por uma explicação racional para o evento - sendo este resultado de ilusões, alucinações, truques ou até mesmo coincidências. Por outro lado, existe a solução sobrenatural, neste caso aceita-se que o ocorrido foi decorrência de forças além da compreensão de mundo atual da personagem, transportando-a a ao universo do desconhecido (TODOROV, 2010). Se 
no fim o leitor/a personagem resolver tomar como verdade uma explicação racional o texto deixa de ser Fantástico e passa a pertencer a um gênero vizinho: o Estranho, que apesar de estar sempre pairando à fragilidade do Fantástico e, por conseguinte, também relacionado ao Maravilhoso - não será aprofundado neste trabalho.

Por outro lado, se a escolha for pela explicação sobrenatural, o texto passa a pertencer Maravilhoso. É válido ressaltar que quando se trata do Maravilhoso, acontecimentos extraordinários já não causam estranheza nas personagens, ou no leitor, já que - uma vez que se aceita que os fundamentos do universo racional não se aplicam àquele onde a narrativa se desenrola - não existe tanta resistência por parte dos envolvidos em relação ao sobrenatural. A partir disso então as reações provocadas pelo extraordinário já não são o foco da atenção, mas muitas vezes a própria origem desses eventos. Conforme Coelho (2000, p. 141) obras que correlatam o real e o imaginário, e situações nas quais o extraordinário quebra a estabilidade do cotidiano, mas onde 0 sobrenatural é encarado com naturalidade pelas personagens - permeando então 0 Maravilhoso - são um grande atrativo para os leitores na sociedade atual. Com isso, Cupertino (2008, p. 31) ressalta que grande parte dos jogos de RPG são pertencentes à categoria desta realidade que transpõe o real e o imaginário, permeando o Maravilhoso.

\section{Conclusão}

É válido ressaltar que este trabalho faz parte de uma pesquisa maior cujo objetivo é desenvolver concept arts para um mundo de RPG digital. A partir das análises feitas aqui, foram delimitadas algumas estratégias para conquistar a afeição do jogador: as concept arts serão desenvolvidas contendo esse caráter lúdico da literatura maravilhosa, a fim de atrair o público-alvo. Porém, para que haja maior identificação do jogador para com a narrativa e os personagens, os elementos apresentados o início da aventura - lê-se aqui os cenários, criaturas e outras alegorias utilizadas - serão mais próximos de um mundo real, com pequenas distorções, ao passo que o sobrenatural será introduzido gradualmente. Com isso então, o prelúdio da narrativa teria um caráter Fantástico, mas com o decorrer da trama e evolução da personagem a ambiguidade será abandonada, fazendo com que a história penda para o Maravilhoso.

\section{Referências}


COELHO, Nelly Novaes. Literatura infantil. Teoria, análise, didática. São Paulo: Moderna, 2000

COUTINHO, Pedro Cardoso. O Labirinto e o Novelo. Entrelaçamentos entre Jogo e Narrativa nos Jogos Multiplayer Online. Anais do II Simpósio Nacional da Associação Brasileira de Pesquisadores em Cibercultura. São Paulo: PUC-SP, 2008.

CUPERTINO, Edson Ribeiro. Vamos jogar RPG? Diálogos com a literatura, o leitor e a autoria. 2008. Dissertação (Mestrado em Estudos Comparados de Literaturas de Língua Portuguesa) - Universidade de São Paulo

LUERSEN, Eduardo Harry. Design e imaginário: Os projetos de cartaz para filmes do subgênero realismo fantástico. Monografia para obtenção de grau de bacharel em Design Gráfico da Universidade Federal de Pelotas, Pelotas, 85 p., 2010

MARTINEZ, Jamil; MUSTARO, Pollyana Notargiacomo; MODESTO, Fábio. ARTRPG: Proposta de desenvolvimento de Tabletop RPG com realidade aumentada. Disponível em:

https://www.researchgate.net/profile/Fabio Alexandre Caravieri Modesto/publication/272 166115 ARTRPG Proposta de desenvolvimento de Tabletop RPG com Realidade A umentada/links/54dcca6c0cf25b09b912cdf1.pdf. Extraído em: 26 de fevereiro de 2017

MÜLLER, Eduardo Fernando. Os conceitos estético-visuais dos jogos digitais. Dissertação (Mestrado em Comunicação Social) - Pontifícia Universidade Católica do Rio Grande do Sul. Porto Alegre, 2011

TODOROV, Tzetan. Introdução à literatura fantástica. São Paulo, Perspectiva, 2010 